資源と素材 (Shigen-to-Sozai)

Vol. 110 p. 689-694 (1994)

LLL総説

\title{
金属間化合物の強度と脆さ* 一結晶塑性異方性は弱点か一
}

\section{馬越佑吉}

\author{
A Review of Studies on Strength and Brittleness of Intermetallic \\ Compounds Focusing on the Plastic Anisotropy \\ by Yukichi UMAKOSHI ${ }^{1}$ \\ 1. Prof., Dr., Department of Materials Science and Engineering, Faculty of Engineering, \\ Osaka University, Yamada - oka, Suita - shi, Osaka 565
}

\section{1.はじめに}

近年の輸送機器の高速化ならびに燃費改善のためのタービン燃焼 温度の上昇は, より高温, 高強度かつ軽量な耐熱材料の開発を求め ている。一般に金属材料の強度は変形温度に依存し, 溶融温度の約 $1 / 2$ 以上の高温になると急速に軟化し，その使用に耐え得なくなる。 しかし, 異種原子が規則的に配列した, いわゆる規則構造を有する 一群の金属間化合物の中には, その強度が温度上昇とともに逆に増 加する “異常強化”之呼ばれる特異な現象を示す場合があり, 耐熱 材料として打ってつけである。例えば, 超合金の主要な強化相であ る $\mathrm{Ni}_{3} \mathrm{Al}$, 新軽量而熱材料として注目されている $\mathrm{TiAl}, \mathrm{Ti}_{3} \mathrm{Al}$ あ るいは $\mathrm{CuZn,} \mathrm{CoTi}, \mathrm{FeCo}, \mathrm{Fe}_{3} \mathrm{Al}$ といった様々な金属間化合物 でこの異常強化現象が認められる ${ }^{122)}$ 。金属間化合物の変形は, し ばしば超格子転位と呼ばれる大きい変位べクトルを有する転位の運 動で律速される。この超格子転位はそのエネルギーおよび運動抵抗 を減じるため逆位相境界 (APB) などの面欠陥を狭み, 変位べク トルの小さい数本の部分転位に分解し，この部分転位対がグループ 運動を余儀なくされるため, 異常強化等の金属間化合物特有の塑性 挙動を示す。

さて, 高温強度という面からのみ考えれば, 合金 $\rightarrow$ 金属間化合 物 ヤセラミックスとその結合状態が金属結合からイオン結合, 共 有結合へと強固になるほど有利となる。このような原子間の結合力 の増加は必然的に加工性の低下, 脆化をむたらし, セラミックスと 同様に金属間化合物においても, その变形能の欠如が実用化への最 大の障害となっているのも事実である。セラミックスは高温におい ても複雑な結晶構造および強固な結合状態により, 転位運動は期待 できず, その変形は点欠陥の拡散によって起こる。したがって高温 使用条件下においても変形能, 破壊勒性の改善は望むべくなく, いわば本質的に脆い。一方, 金属間化合物の変形は転位運動により 律速され, 高温では決して脆くなくセラミックスとは本質的に異な る。

金属間化合物の変形は, 転位がある結晶面上を運動する之りによっ て起こるが, 異種原子が規則的に配列するため, 通常の合金に比べ ればより複雑な対称性の低い規則構造を取るため, その活動し得る 过り系の数は少なく, また前述のように超格子部分転位対としてグ

* 1994 年 4 月 16 日受付 5 月 23 日受理

1. 工博 大阪大学教授 工学部材料物性工学科

キーワード：金属間化合物，勒性，破壊，塑性異方性，疲労
ループ運動するため, 特定の面上のみで之りが起こり, 交差之りが 困難であるといった極めて強い結晶塑性異方性を示す。多結晶を無 理なく変形させるためには, 結晶粒界における歪の連続性という観 点から 5 種以上の独立した过り系を必要とし ${ }^{3)}$, そのため, 金属間 化合物の示す強い異方性, 活動过り系の低下が脆さの一因と考えら れている。

本稿では, 金属間化合物の強度, 变形能と結晶塑性異方性との関 わり合い, その異方性を積極的に利用する方策について, 軽量耐熱 材料としてその実用化が期待されている TiAl 金属間化合物の結果 を中心に述べる。

\section{2. 金属間化合物の脆さとその原因}

結晶の変形は, 主に転位の運動ならびに増殖によってあたらされ, そのため高融点, 強い原子間結合力, 複雑な結晶構造を有するある 種の金属間化合物においては, , 転位の増殖それ自体が困難であっ たり, 転位芯の構造が複雑であり運動抵抗が大きく, 変形は容易で ない。このような金属間化合物は単結晶, 多結晶を問わず変形は困 難であり, 結晶粒微細化等の組織制御，合金組成の調整ならびに添 加元素の探索といった対策では改善し得なく，いわば本質的に脆い。 このような本質的に脆い場合は別にしても，金属間化合物の変形能 は通常の合金に比べ結晶粒界，不純物元素，合金組成，水素等の使 用環境によって著しく阻害される場合がある。例えば，耐熱性に優 れた $\mathrm{Ni}_{3} \mathrm{Al}$ はFig. 1 に示すように単結晶では充分な変形能を示し, 圧延加工も可能であるが, 多結晶では極めて脆く降伏することなく 粒界で破壊する。粒界近傍での変形歪の連続性という意味からも活 動之係が減少する結晶塑性異方性の強い金属間化合物は粒界で破 壊する場合が多い。しかし， $\mathrm{Ni}_{3} \mathrm{Al}$ は面心立方晶を基本格子とする 対称性のよい $\mathrm{L}_{2}$ 型規則構造を有し, その过りは $\{110\}\langle 110\rangle$ 系 で起こり, 过り系の数という点では問題なく, その粒界脆化は粒界 強度そのあのに問題がある。このような粒界脆化の原因は, 規則合 金特有の粒界構造 ${ }^{4)}, \mathrm{Al}$ 原子による電子の局在化に起因する粒界 近傍の原子間結合力の低下 ${ }^{5)}$ など様々な要因が考えられるが， $\mathrm{Al}$ 濃度の低減とともに微量 B 添加による粒界偏析が Fig. 1 に示すよ うに粒界脆化抑制に効果的である ${ }^{6)}$ 。

また, 金属間化合物の加工性は試験雾囲気に強く依存し, いわゆ る環境脆化を示す場合がある。多結晶の $\mathrm{Ni}_{3} \mathrm{Al}$ は前述したごとく 非常に脆く, その原因は粒界脆化にある。しかし, 真空中で試験す ると, 状況は一変し, かなりの变形能を示し, 逆に $\mathrm{H}_{2}$ ガス雾囲気 


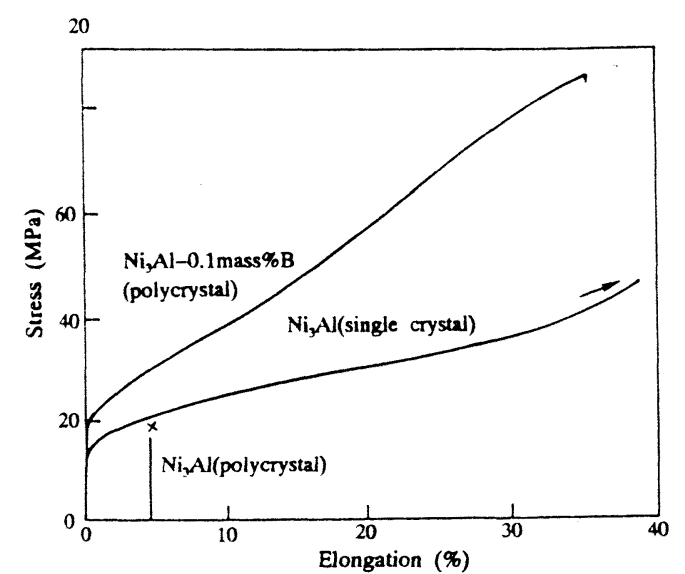

Fig. 1 Stress - strain curves of $\mathrm{Ni}_{3} \mathrm{Al}$ single and polycrystals with and without boron.
中あるいは水素イオンチャージ中での変形では, B 添加材において あ変形能は低下する。このような傾向は $\mathrm{Ni}_{3} \mathrm{Al}$ に限らず, CoTi, TiAl，FeCoなどかなりの金属間化合物において認められ，水素が 関与した水素脆化現象と呼ばれている77。大気中に水素は存在しな いが, 空気中の水蒸気が金属表面で反応し, 例えば

$3 \mathrm{H}_{2} \mathrm{O}+2 \mathrm{Al} \rightarrow \mathrm{Al}_{2} \mathrm{O}_{3}+6 \mathrm{H}$

として金属間化合物表面で水素を形成し，材料中に侵入し運動転位 との相互作用により破壊の原因となると考えられている。このよう な水素脆性は $\mathrm{B}, \mathrm{C}$ などの侵入型元素の微量添加, $\mathrm{Ni}_{3} \mathrm{Al}$ への $\mathrm{Si}$, $\mathrm{TiAl}$ 中への $\mathrm{Cr}$ などの置換元素の添加，あるいは表面酸化被膜の 形成による水素の侵入, 拡散の抑制によりある程度改善される。こ のような水素の侵入は変形能の著しい劣化をもたらすが, 降伏応力 にはほとんど影響を及ぼさない。金属間化合物の脆さの原因が，こ のような水素脆化によるとすれば，水素の侵入ならびに拡散を抑制 する微量添加元素の探索により，金属間化合物の実用化への新たな 展望が開かれるかもしれない。

さて，金属間化合物の機械的性質はその合金組成，化学量論組成 からのずれによって著しく影響を受け，原子空孔が導入される構造 欠陥を有する場合, 著しく硬化し脆くなる。この場合, その構成元 素による硬化は等価ではなく, 例えば NiAlにおいて Ni 過剩側で は本来 $\mathrm{Al}$ 原子が占有すべき位置が $\mathrm{Ni}$ 原子に置換される。一方, $\mathrm{Al}$ 過㮃側では $\mathrm{Ni}$ 原子位置に空孔が導入されるため, その変形は 起こり難くなる ${ }^{8)}$ 。このような構造欠陥は通常の合金において熱平 衡で導入される空孔濃度に比べれば非常に多く, 脆化の原因ともな る。このような組成の変化はすべての金属間化合物において脆化を むたらすとは限らず，例えば FeAl における Fe 側組成へのずれは, 規則度の低下, 逆位相境界エネルギーの隇少をむたらし, 金属間化 合物をより合金的にし，変形能は改善される ${ }^{9)}$ 。

従来, 金属間化合物の変形において, 不純物元素, 特に $\mathrm{C}, \mathrm{O}, \mathrm{N}$ 等の侵入型元素にあまり注意が払われていなかった。しかし $\mathrm{Al}$, $\mathrm{Cu}$ などの面心立方金属に比べ, $\alpha-\mathrm{Fe}, \mathrm{Mo}$, Ta といった体心立 方金属においては, その変形を担う転位芯の構造が重要であり, 侵 入型元素との相互作用によりその変形挙動は著しく影響されること はよく知られている。金属間化合物においても，その基本格子の特 性が塑性挙動に反映し, $\mathrm{Ni}_{3} \mathrm{Al}$ は面心立方晶として振る舞うため 低温ではそれほど脆くない。一方, NiAl は B2 型構造を取り, 体 心立方晶としての特徵を受け継ぐため転位運動には熱活性を必要と し, 低温ではその変形は難しく, また $\mathrm{C}, \mathrm{O}, \mathrm{N}$ などの侵入型元素 の增加は著しく加工性を損ねる。最近, $\mathrm{Ni}_{3} \mathrm{Al}$ より高温で使用し得 るタービン翼材などの耐熱材料として NiAl が注目されており, そ

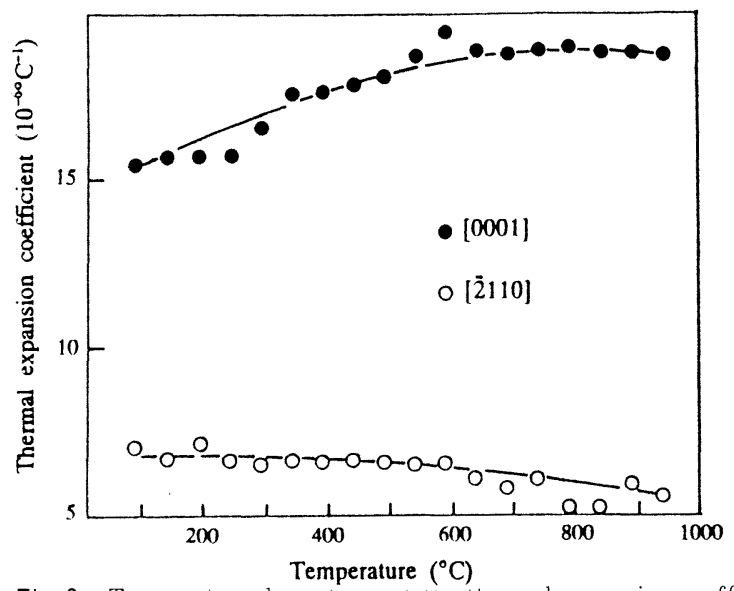

Fig. 2 Temperature dependence of the thermal expansion coefficient of $\mathrm{Ti}_{5} \mathrm{Si}_{3}$ single crystals along the a - and c - axes.

の組成をより化学量論組成に近いものとし, また不純物元素を低減 することにより, その変形能改善が図られている。

金属材料の変形は, 転位の導入, 増殖および運動によってもたら されるのは前述した通りである。一般に結晶中に転位を形成するた めに必要な応力は, その運動に要する応力に比べ大きい。特に金属 間化合物中の超格子転位のように大きい変位ベクトルを有する転位 は大きいエネルギーを有し，その形成には非常に大きい応力を必要 とし，しばしば破壊の原因ともなる。例えば， NiAl， $\mathrm{MoSi}_{2}$ など の変形が困難な化合物においても熱間押出し等の際に導入された転 位が残存する場合には, 転位運動は比較的容易に起こり変形能が改 善される可能性があり,このような可動転位の導入といった観点か らの検討む必要であろう。

金属間化合物の破壊は，その強い結晶異方性を反映して特定の原 子面でへき開破壊が起こる場合がある。例えば超高温耐熱材料とし て期待され，2,000 ${ }^{\circ} \mathrm{C}$ 以上の融点を有する $\mathrm{Ti}_{5} \mathrm{Si}_{3}$ がある。このシ リサイドは六方晶を基本格子とする $\mathrm{D} 88$ 型構造と呼ばれるかなり 複雑な構造を取り, その原子配列から変形の起こり得る面は底面で あるが, 実際の変形は双晶によって起こり, 双晶が起こり難い方位 では底面上でへき開破壊する。この単結晶の熱膨脹率の方位依存性 および温度依存性の測定結果を Fig. 2 に示す。熱膨脹率は原子間 結合力の非調和項を反映して起こり, c 軸方向の熱膨脹率は a 軸方 向に比べて大きく，この方向の原子間結合力の低下を意味している。 このような結合力の低下が底面でのへき開破壊をむたらし, 結晶構 造ならびに原子間結合力の異方性が強い金属間化合物においてはこ のようなへき開破壊が誘発されやすい。

\section{3.过りの異方性}

金属材料の変形は, 特定の結晶面上の転位運動の結果としての过 りによって起こるため, 粘土のようなものと異なり, 基本的に異方 性を伴う。双晶変形を例に取れば, Fig. 3 に示すように引張応力下 では（112）面上で [111] 方向に上面の原子は移動し, $\mathrm{AB}$ 面を境 に上下の面上の原子は鏡面対称となり，いわゆる双晶を形成する。 しかし, 同一方位の結晶を圧縮変形すると, $[11 \overline{1}]$ 方向への変位, いわゆる反双晶方向への原子移動が起こり，上下の面上の原子は鏡 面対称とはならず, 原子間距離は近づき, 現実にはこのような変形 は起こり難く, 双晶変形は強い異方性を示す。転位運動においても, その転位芯構造の非対称を反映して, 異方性を示す。特に金属間化 合物中では異種原子位置が特定されているため, 超格子転位の分解 形態および面欠陥エネルギーが結晶面によって異なるため, 过りの 起こりやすさには極めて強い異方性を示す。例えば軽量耐熱材料スー 


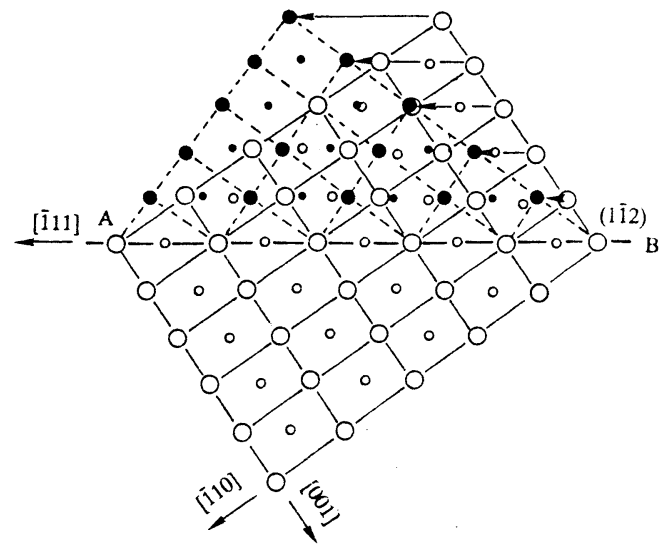

Fig. 3 Atomic arrangements of a deformation twin in bcc crystal. Open and closed circles represent atoms before and after deformation, respectively.

パー $\alpha_{2}$ として使用されている $\mathrm{Ti}_{3} \mathrm{Al}$ 系金属間化合物の場合を示 す。この化合物は $\mathrm{D} 0_{19}$ 型構造と呼ばれる六方晶系構造を示し, そ の原子配列から予想される变形可能な面は $\{1010\}$ 柱面, (0001) 底 面および $\{1121\}$ 釷面である。しかし，これらの面上を運動し得る 転位の種類, 分解形態の違いにより变形の起こりやすさは等しくな く, Fig. 4 に示すようにその変形に必要な臨界分解剪断応力 （CRSS）は著しく異なる。柱面过りが最も起こりやすく, 次いで 底面之りとなり錘面过りは約 8 倍近い変形応力を必要とし， [0001] 近傍のごく限られた応力軸を持つ結晶においてしか現れない11)。ま た，その温度依存性も著しく異なり柱面过りの CRSS は温度上昇 に伴い単調に減少するが, 底面过りのそれは, $500{ }^{\circ} \mathrm{C}$ 近傍までゅる やかに減少した後急速に低下する。錘面之りの場合には逆に温度上 昇とと屯に增加し, $500{ }^{\circ} \mathrm{C}$ 近傍にピークを持ついわゆる異常強化現 象を示す。このような过りの強い異方性を反映して多結晶 $\mathrm{Ti}_{3} \mathrm{Al}$ は低温では脆く, そのため体心立方晶としての $\beta$ 相と共存する形で スーパー $\alpha_{2}$ として用いられている。このような非常に脆い金属間 化合物む, 特定过りに限定すれば, 必ずしも脆くなく, 例えば, $\mathrm{Ti}_{3} \mathrm{Al}$ の柱面沪りは比較的容易に起こる。

Fig. 5 は $\mathrm{Ti}_{3} \mathrm{Al}$ 単結晶を柱面过りが起こりやすい方位に切り出 し, 压延に伴う硬度変化を示したものであるが, 柱面过りのみに限 定すればあまり硬化することなく, 約 $50 \%$ 近い圧延加工も可能で

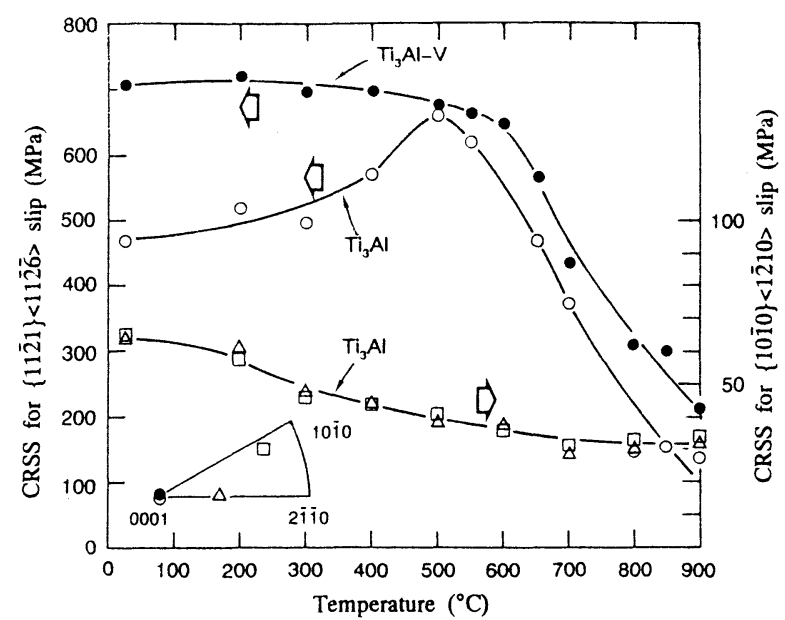

Fig. 4 CRSS for $\{10 \overline{10}\}<\overline{2} 10\rangle$ and $\{11 \overline{1} 1\}<1 \overline{112 \overline{6}}>$ slip of ordered $\mathrm{Ti}_{3} \mathrm{Al}$ and $\mathrm{Ti}_{3} \mathrm{Al}-\mathrm{V}$ single crystals as a function of temperature.

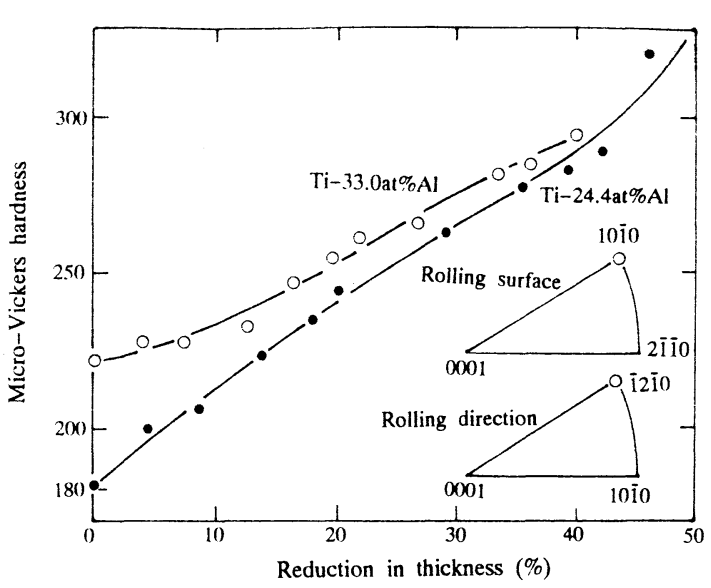

Fig. 5 Variation of hardness of cold rolled $\mathrm{Ti}_{3} \mathrm{Al}$ single crystals with reduction in thickness.

ある ${ }^{12)}$ 。また $\mathrm{NbSi}_{2}, \mathrm{TaSi}_{2}$ は $2,000{ }^{\circ} \mathrm{C}$ 近傍に融点を持ち, 耐酸化 性にも優れ超高温而熱材料として期待されているが，Si の強い共 有結合性故に極めて脆い。このシリサイドは C40 型と呼ばれる六 方晶系構造を有し，それ故強い結晶塑性異方性を示す。このような シリサイドにおいても単結晶を用いた底面过りに限定すれば，室温 においても変形が可能となる。このような金属間化合物の持つ強い 結晶塑性異方性を利用することにより, 特定の面上での変形を起こ させることが可能である。 $\mathrm{NbSi}_{2}, \mathrm{TaSi}_{2}$ の変形は底面のみで起こ り,そのため多結晶を変形することは困難であり,このシリサイド 単体を耐熱構造材料として使用することはできない。しかし，例え ば $\mathrm{MoSi}_{2}$ 上の複合化により低温におけるクラック伝播径路の変更 という意味での破壊勒性の改善には, この異方性を積極的に利用で きるであろう。

\section{4，TiAl 系金属間化合物の結晶塑性異方性}

TiAl は軽量かつ高温強度, 耐酸化性に優れた新しい軽量耐熱材 料としてその開発が期待されている。この化合物は $\mathrm{L} 10$ 型（ $\gamma$ 相） と呼ばれる面心正方晶を取り, a 軸および $\mathrm{c}$ 軸方向の原子配列は等 価ではなく, $1 / 2<110]$ 普通転位, <101] 超格子転位, <112] \{111\} 双晶が变形に寄与する。結晶構造, 活動転位の分解形態等か らは充分な変形能が期待されるが, 現実には $\gamma$ 単相は室温におい てほとんど伸びを示さない。この TiAl の強度ならびに変形能はそ の合金組成に強く依存し，化学量論組成より $\mathrm{Ti}$ 側組成において強 度, 変形能とも優れた特性を示す。この組成の合金は $\gamma$ 相に $\mathrm{D} 0_{19}$ 型構造を有する $\alpha_{2}$ 相が少量混在する 2 相層状組織を示し, それ故 この層状組織の形成が変形能改善をむたらすと考えられていた。し かし $\gamma$ 相それ自体が脆く，しかも $\alpha_{2}$ 相は前述したように，その結 晶構造から考えて充分な塑性を示すとは思えない。このような塑性 に欠ける 2 相の混在によりその変形能改善がもたらされるとは考え 難く,この化合物の塑性挙動ならびに層状組織の役割を明らかにす る必要がある。

TiAl 合金を帯溶融法で $2.5 \sim 10 \mathrm{~mm} / \mathrm{h}$ 程度の非常に遅い速度で 結晶成長させると層状組織を一方向に制御した結晶粒界のない PST 結晶と呼ばれる Fig. 6 に示すような試料が得られる。この結 晶中では冷却中に $\alpha$ 相から $\gamma$ 相が晶出し, その際, $\mathrm{D} 0_{19}$ 型構造の (0001) 面と $\mathrm{L} 10$ 型構造の最稠密面である $\{111\}$ 面上の原子配列が 類似していることから， $\{111\} \quad \gamma / /(0001) \alpha_{2},<110>\gamma / /$ $\left\langle 11 \overline{20}>\alpha_{2}\right.$ なる整合関係を満足するように $\alpha_{2}$ 相は $\gamma$ 相中で層 状に配列する。また， $\gamma$ 相中にはその変態の際に多数のドメイン 
(a)<smiles>Cc1ccc([18OH])c([18OH])c1</smiles>

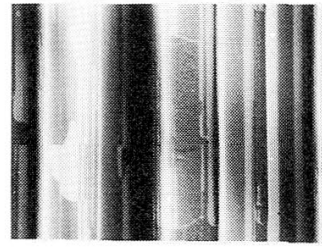

(a)

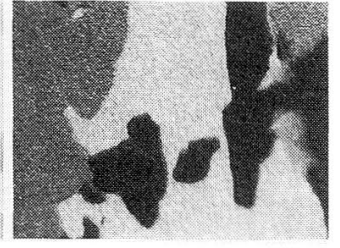

(b) $20 \mu \mathrm{m}$
Fig. 6 Optical mirographs of $\mathrm{Ti}-49.1$ at \% Al PST crystal grown at $2.5 \mathrm{~mm} / \mathrm{h}$. (a) oriented lamellae, (b) ordered domains in $\gamma$ phase.

ならびに双晶が形成される。このような PST 結晶を用いてその塑 性異方性を調べた。結晶方位依存性を簡単に表すため, 層界面と応 力軸とのなす角を $\phi$ こし, 降伏応力ならびに破壊伸びの $\phi$ 依存性

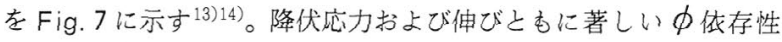
を示し， $\phi=45^{\circ}$ の場合，降伏応力は最も低く，しかも充分な伸び を示す。 $\phi$ 值が $45^{\circ}$ から $0^{\circ}$ あるいは $90^{\circ}$ 方向へ変化するに従い, 降伏応力は著しく増加し, 逆に伸びは急速に減少する。さて, 前述 の $\alpha_{2}$ 相および $\gamma$ 相の整合関係より, 層界面は $\gamma$ 相について見れ ば $\{111\}$ 面に平行である。 $\gamma$ 相の変形は, その結晶構造から明ら かなごとく, $\{111\}$ 面上で起こる。 $\phi=45^{\circ}$ の場合，等価な他の $\{111\}$ に比べ層界面に平行な $\gamma$ 相の $\{111\}$ 面上のシュミット因子 が最大となることから变形は $\gamma$ 相中の層界面に平行な $\{111\}$ 面上 のみで起こり, 変形に対する $\alpha_{2}$ 相の寄与はほとんどないと思われ る。このような $\gamma$ 相のみの变形であるにもかかわらず， $\gamma$ 単相の 場合と比へ低い降伏応力で変形し, しかも優れた加工性を示し, 決 して脆くない。従来, TiAl は $\gamma$ 単相状態では脆く, 変形能改善の ためには $\alpha_{2}$ 相を含む層状組織が必要しされていた。しかし，鋳造 状態で $\gamma$ 単相とするためにはその合金組成を化学量論組成上り大 幅に $\mathrm{Al}$ 側にする必要がある。一方, 層状組織を形成する $\alpha_{2}$ 相と 共存する $\gamma$ 相の組成は化学量論組成よりやや Ti 側にある。多くの 金属間化合物の機械的性質, 変形挙動がその合金組成に著しく依存

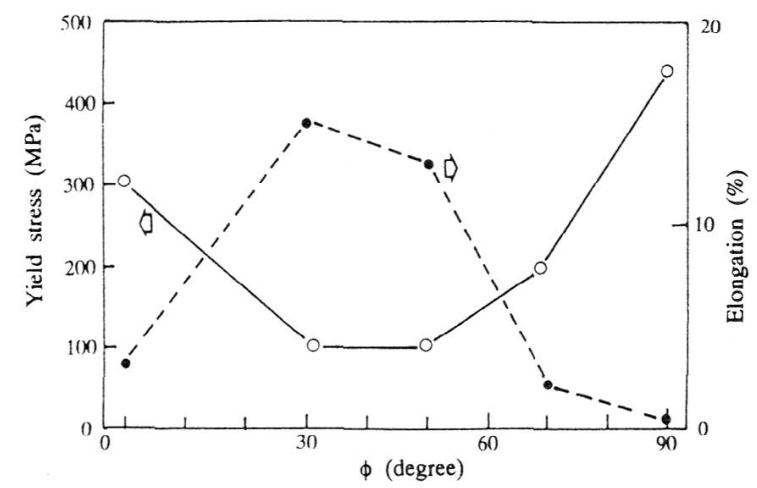

Fig. 7 Orientation dependence of the yield stress and elongation of TiAl PST crystals. $\phi$ is the angle between the lamellar planes and tensile axis.

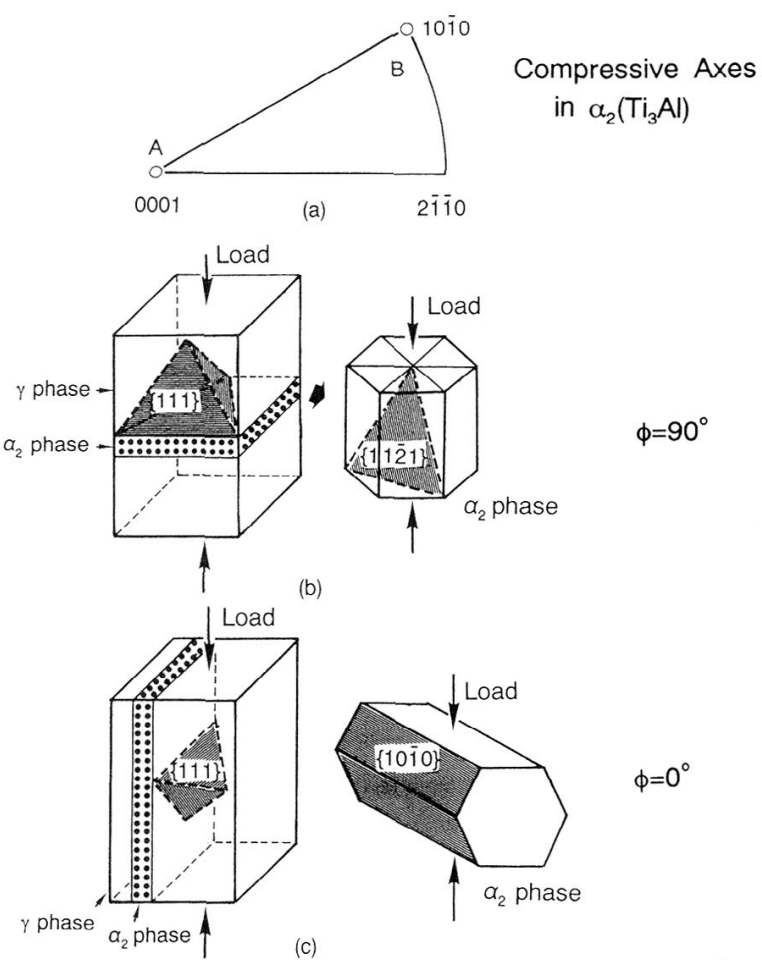

Fig. 8 Compressive axes and slip planes in lamellae of TiAl PST crystal. (a) a stereographic projection of compressive axes $\mathrm{A}\left(\phi=90^{\circ}\right)$ and $\mathrm{B}\left(\phi=0^{\circ}\right)$ of $\alpha_{2}$ phase, (b) a schematic drawing of slip planes at $\phi=90^{\circ}$, (c) a schematic drawing of ship planes at $\phi=0^{\circ}$.

することを考えれば， $\gamma$ 相それ自体は決して脆くはなく， $\gamma$ 単相 の脆さはその合金組成が $\mathrm{Al}$ 側にずれていることがその原因と考え られる。さて， $\phi$ が $45^{\circ}$ からずれると， $\alpha_{2}$ 相と交差する他の $\{111\}$ 面上の过りが支配的となる。この面上において転位の運動は $\alpha{ }_{2}$ 相 ならびに $\gamma$ 相内のドメイン境界により止められ, 高い降伏応力を 生み出す原因となる。しかし，このような $\alpha_{2}$ 相ならびにその層界 面での転位運動の拘束という面からのみ考えれば， $\phi=0^{\circ}$ ならび に $90^{\circ}$ において同様の効果が期待されるはずであるが, その両者の 降伏応力ならびに伸びには大きい違いが認められる。

さて，そのような違いを結晶塑性の立場から考えてみる。いま， $\phi=0^{\circ}$ ならびに $90^{\circ}$ の場合の $\alpha_{2}$ 相の応力軸は Fig. 8 のようにな る。特に $\alpha_{2}$ 相の変形モードの応力軸依存型を考えれば, Fig. 8 に 示すように $\phi=0^{\circ}$ の場合には柱面过りが可能である。一方, $\phi=$ $90^{\circ}$ の場合においては, 柱面过りならびに底面过りは起こり得なく, 唯一釷面之りのみが可能となる。 Fig. 4 に示した Ti 3 Al 単結晶の 結果に見られるように, これらの过りの CRSSならびにその温度 依存性は大きく異なり，このような $\alpha_{2}$ 相の过りならびにその変形 応力の違いと異方性が $\mathrm{TiAl}$ の強い塑性異方性の原因となってい $3^{13) 15)}$ 。変形能という立場からすれば， $\alpha_{2}$ 相中の錘面过りの高い CRSS は層界面での破壊を誘発する原因ともなる。そのため鍾面之 りを活性化する合金元素の探索が必要とされる。また底面过りにつ いて見れば，単結晶においても極端な不均一変形を示し，試料表面 に段差を生じてクラック発生の原因ともなる。層状 TiAl の破壊が $\alpha_{2}$ 相の底面上でもしばしば認められる事実は, このような底面过 りの変形モードにも関係していると思われ, この面からの変形能改 善策む模索する必要がある。

層状組織に由来する TiAlの強い塑性異方性は, この化合物の変 形能という意味では好ましくない。一方, 化学量論組成に近い $\gamma$ 
相それ自体は圧延加工も可能なほどの加工性を示すが，その強度は 極端に低く,この状態では耐熱材料として使用し得ない。TiAl が 魅力ある軽量耐熱材料として注目される由縁は, 層状組織を形成す る $\alpha_{2}$ 相の塑性異方性を利用しての強化に負うところが大きい。ま た変形能という点から考えれば，过りを層界面に平行な $\{111\}$ 面上

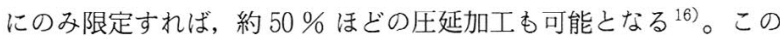
ようにその塑性異方性の変形挙動に果たす役割を正確に認識し，こ れを積極的に利用する組織制御ならびに設計上の工夫が必要である。

\section{TiAlの疲労ならびに破壊の異方性}

TiAl を実用材料として仕上げるためには, 単に単調負荷応力の 屯とでの強度, 勒性のみならず交番応力下での変形, すなわち疲労 機構の解明之その特性改善が強く求められている。微視的立場から 見れば，転位の往復運動ならびにをの際の相互作用によって生み出 される微細組織および表面起状が, 疲労硬化ひいては破壊を誘発し, この際, 塑性異方性ならびに不均一変形の影響がより顕著に現われ

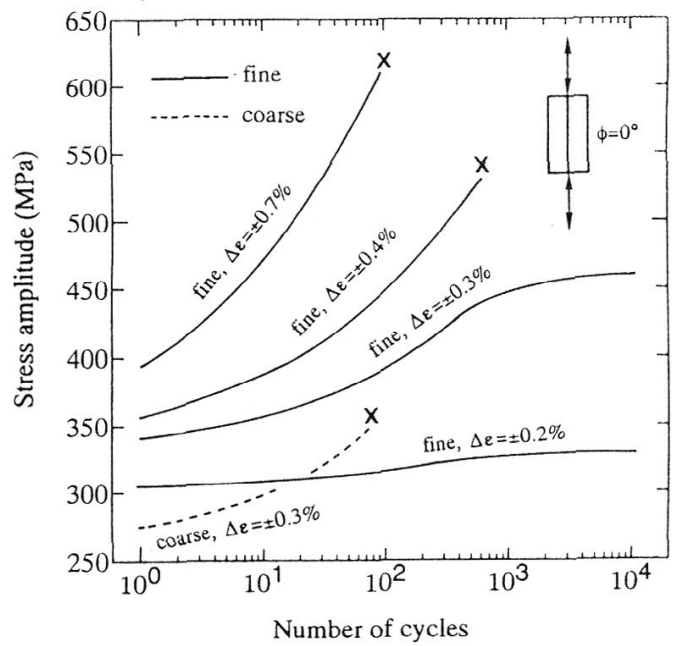

Fig. 9 Cyclic hardening curves of $\mathrm{Ti}-49.1$ at $\% \mathrm{Al}$ (fine lamellae) and Ti -50.8 at \% Al (coarse lamellae) PST crystals with $\phi$ $=0^{\circ}$ at various strain amplitudes $(\Delta \varepsilon)$. $\phi$ is the angle between the lamellar planes and the loading axis.

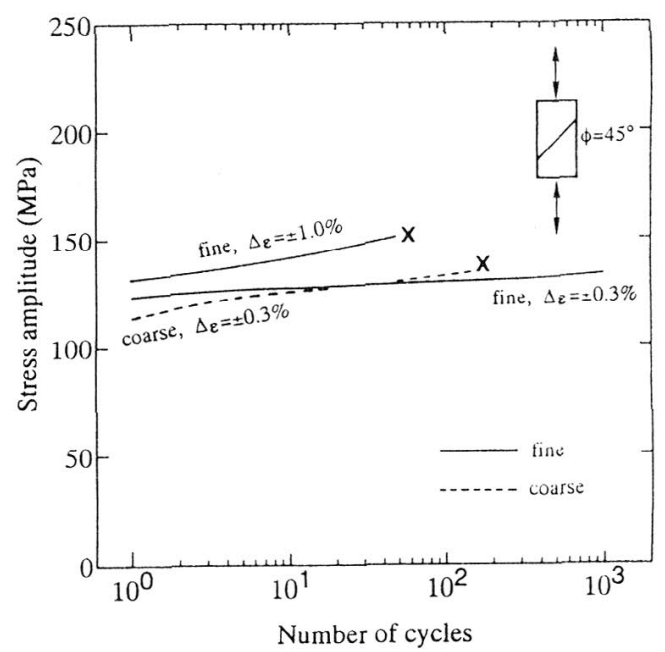

Fig. 10 Cyclic hardening curves of $\mathrm{Ti}-49.1$ at $\% \mathrm{Al}$ (fine lamellae) and $\mathrm{Ti}-50.8$ at $\% \mathrm{Al}$ (coarse lamellae) PST crystals with $\phi$ $-45^{\circ}$ at various strain amplitudes $(\Delta \varepsilon)$
る。

Fig. 9 㧍よび 10 は TiAl PST 結晶を室温において全歪制御で疲

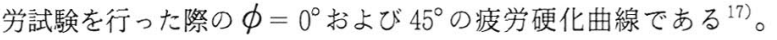
層界面の拘束を受けず， $\gamma$ 相中のみで变形が進行する $\phi=45^{\circ}$ と, $\alpha_{2}$ 相に掞いて転位ならびに双晶の運動が抑制される $\phi=0^{\circ}$ の場 合では，硬化曲線に顕著な違いが認められる。 $\phi=0^{\circ}$ の場合, 繰 り返し变形量の増加に伴い硬化が起こる。付加歪振幅の増加に伴っ て, 応力ならびに硬化率が增加し, 疲労寿命む短くなるのは一般的 な現象である。一方， $\phi=45^{\circ}$ の硬化曲線は，変形量が增しても低 硬化率で推移し，ほとんど硬化することなく破壊に到る特異な挙動 を示す。压縮あるいは引張といった単調変形において， $\alpha_{2}$ 相なら びに層状組織の存在は, 強化には寄与するが, 変形能という面から すればマイナスに作用し，層界面と転位との相互作用の大きい $\phi$ $=0^{\circ}$ および $90^{\circ}$ では変形は阻害されるが， $\phi=45^{\circ}$ の場合には良好 な変形能を示し, 圧延加工む可能であった。しかし交番応力下の変 形では, 破壊に到る繰り返し変形量は $\phi=45^{\circ}$ は $0^{\circ}$ に比べて必ず しも多くなく，小さい応力振幅を考えれば疲労寿命という面からは むしろ劣化し, 単調変形とは異なった挙動を示す。しかし，いずれ の方位に扔いても組織の微細化は疲労特性には良好に作用している。 このような変形モードの違いによる塑性異方性の変化は何に起因 するのであろうか。周知のように, $\alpha_{2} / \gamma$ 層界面に比べ $\gamma$ 層中の ドメイン境界は, 転位ならびに双晶の運動に対し, あまり大きい障 害とはならない。そのため $\phi=45^{\circ}$ の交番応力下での転位の往復運 動は長距離におよび，その多くは結晶外に抜ける。しかも層界面に 平行な同一 $\{111\}$ 面上で平面的な運動を繰り返すため, 硬化する ことなく大きい表面起状を形成し, これが龟裂の発生, 破壊へと繋 がるため疲労破壊抵抗は小さい。一方， $\phi=0^{\circ}$ の場合，その疲労 変形組織はFig. 11 に示すように著しい異方性を示す。高密度の転 位が局在化した束状組織を形成する部分と変形双晶が主に認められ る部分に大別される。これらの転位ならびに双晶は層界面において 拘束されるため, 交番応力下では特定のドメイン内のみでの転位の 往復運動ならびに反応が繰り返され, 高密度転位領域の形成により 急速に硬化する。このような転位の運動距離ならびに二次过り系の 活動の有無が硬化曲線の大きい異方性を生み出す。さて, 双晶の形 成には圧縮あるいは引張変形モードで強い異方性が存在し, 双晶が 多数認められるドメインにおいても, 交番応力下の双晶の往復運動 は考え難い。この領域においては転位の運動に要する応力が大きい ため, 变形初期には転位密度は小さいが, 他の領域における転位反 応による硬化により負荷応力が上昇し, このドメイン内においてす

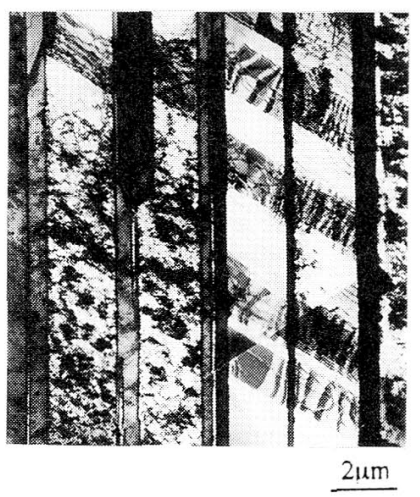

Fig. 11 Electrron micrograph of Ti-49.1 at \% Al PST crystal cyclically deformed at $\phi=0^{\circ}$. The total strain amplitude $(\Delta \varepsilon)$ and the number of cycles $(N)$ are $\pm 0.3 \%$ and 1,000 cycles, respectively. 
転位が活動し得るようになる。この際，双晶発生によって生じた局 部歪ならびに大きい表面起伏部分が起点となり, 変形が集中し, こ の部分が亀裂発生源として働き，破壊に到る可能性がある。このよ うに変形双晶それ自体が疲労寿命を決定するわけではないが，それ を媒介としての局部的な变形の進行が疲労破壊をむたらす。しかし， 層界面それ自体は疲労寿命にとって必ずしも障害とはならず，むし ろ良好に作用している。

さて, 実用材料の信頼性という面からすれば，亀裂の発生，伝播 を抑制し，その運動抵抗を增す破壊勒性の改善が重要な課題である。 転位が容易に運動し変形が起こる, いわゆる塑性領域の存在は亀裂 先端の応力緩和に繋がり破壊勒性の改善には有利である。しかし， 材料強度の上昇は必然的に塑性変形を困難にし，そのため亀裂先端 の変形による応力緩和による破壊勒性の改善のためには, 亀裂の発 生ならびに伝播抵抗を増すことはもちろん，亀裂進展経路を複雑化 し, 吸収エネルギーの増加による破壊勒性改善を図る必要がある。 例えば, 層状 TiAl の場合, その $\alpha_{2}$ 相ならびに層状組織の強い異 方性に起因して, 強度は增加するが延性は低下する。しかし，この ような強い異方性は亀裂進展にも強く反映し, 首界面ならびに $\alpha_{2}$ 相の底面上における亀裂伝播を容易にする。したがって層界面に垂 直方向に応力を負荷した場合, 亀裂は $\gamma$ 相中と $\alpha_{2}$ 相の底面ある いは層界面を交互に通過する形で進展する。このような龟裂伝播経 路の変更は, その層間隔が小さくなるほど容易となり, そのため破 壊勒性はより改善される。塑性変形の難易, 亀裂発生が直接関与す る延性という観点からすれば, 異方性が強く現われる層状組織は好 ましくなく,より等方的な等軸粒組織が望ましい。しかし，TiAl の高強度は $\alpha_{2}$ 相の強い塑性異方性に負うところが大きい。また， 破壊という面から見れば，強い結晶塑性異方性の特性を積極的に生 かすため, 層状組織の利用を含めての複相合金の方位関係, 分布, 寸法等を調整し，亀裂伝播経路制御による破壊勒性改善が期待でき る。

\section{6.おわりに}

金属材料の変形が転位, 双晶に依存し，その運動が特定の結晶面 で起こることを考えれば, その強度, 变形能といった機械的性質に 異方性が生じるのは必然である。結晶構造に異種原子の寄与があり, その原子間結合力が通常の合金より強いという点を考えれば，金属 間化合物がより強い異方性を示すのは当然といえる。このような塑 性異方性は, 変形の連続性を阻害し, 延性という点から考えれば好 ましくない。しかし，我々が目の当たりにするある種の金属間化合 物の脆さにおいても，その原因が塑性異方性に由来するとすれば,
ある特定の変形挙動に限定することにより変形可能となる。例えば, $2,000{ }^{\circ} \mathrm{C}$ 近傍の高融点を持ち, 共有結合性が強く, 非常に脆いと思 われる $\mathrm{NbSi}_{2}$ であっても底面过りのみに変形を制御すれば決して 脆くない場合もある。このような異方性を利用しての特殊な変形条 件下での加工法という面からも考慮する余地がある。

また，破壊勒性という面から見れば，その亀裂伝播抵抗を上げる のが本筋であるが, 高強度材料に扔いてはこれが困難な場合がある。 例えば超高温材料として期待される $\mathrm{MoSi}_{2}$ は高温使用条件下の強 度, 勒性, 耐酸化性には優れているが, 低温における延性, 破壊勒 性には欠ける。この種シリサイドの延性改善を合金組成, 組織制御 により図ることは不可能に近い。例えば, $\mathrm{NbSi}_{2}, \mathrm{TaSi}_{2}, \mathrm{CoSi}$ どの高融点であるが特定の変形条件に限り変形可能なシリサイドと の複合化による亀裂先端の塑性変形, あるいは破壊の異方性を利用 しての亀裂の優先的進展経路の誘導により破壊勒性の改善も期待さ れる。このように一見金属間化合物の大きい弱点とされる塑性異方 性であってあ，その本質を理解し，これを積極的に利用する方策を 考えれば，実用耐熱材料としての金属間化合物が，より現実のもの となるであろう。

\section{引用 文 献}

1）山口正治・馬越佑吉：金属間化合物，日刊工業新聞社刊（1984）

2) Yamaguchi, M. and Umakoshi, Y. : Progress in Materials Science, Vol. 34, p. 1, (1990)

3) von Mises, R. : Z. angew. Math. Mech., Vol. 8, p. 161, (1928)

4) Takasugi, T. and Izumi, O. : Acta Metall., Vol. 33, p. 1247, (1985)

5) Taub, A. L. and Briant, C. L. : Acta Metall. Vol. 35, p. 1597, (1987)

6）青木 清 - 和泉 修: 日本金属学会, Vol. 43, p. 359, (1979)

7) Liu, C. T. and George, E. P. : MRS symp. High Temperature Intermetallics IV., p. 213, (1991)

8) Westbrook, J. H. : J. Electrochem. Chem. Soc., Vol. 103, p. 54, (1956)

9) Crimp, M. A., Vedula, K. M. and Gaydosh, D. J. : High Temperature Intermetallic Alloys II MRS symp. Proc. Vol. 81, p. 499, (1987)

10) Nakashima, T. and Umakoshi, Y. : Phil. Mag. Lett., Vol. 66, p. 317, (1992)

11) Umakoshi, Y., Nakano, T., Takenaka, T., Sumimoto, K. and Yamane, T. : Acta metall. mater., Vol. 41, p. 1149, (1993)

12) Umakoshi, Y., Nakano, T., Sumimoto, K. and Maeda, Y. : Mat. Res. Soc. Symp. Proc. Vol. 288, p. 441, (1993)

13) Umakoshi, Y. and Nakano, T., : ISIJ Inter., Vol. 32, p. 1339, (1992)

14) Inui, H., Oh, M. H., Nakamura, A. and Yamaguchi, M. : Acta metall. mater., Vol. 40, p. 3095, (1992)

15) Umakoshi, Y. and Nakano, T. : Acta metall. mater., Vol. 41, p. 1155, (1993)

16) Nishitani, S. R., Oh, M. H., Nakamura, A., Fujiwara, T. andYamaguchi, M.: J. Mater. Res., Vol. 5, p. 484, (1990)

17) Umakoshi, Y., Yasuda, H. Y. and Nakano, T. : Proc. 3rd Jap. Inter. SAMPE p. 1329, (1993) 